Int. J. Dev. Biol. 56: 263-272

doi: $10.1387 / \mathrm{ijdb} .113384 \mathrm{ps}$

\title{
Bimodal distribution of motility and cell fate in Dictyostelium discoideum
}

\author{
PAVANA GOURY-SISTLA ${ }^{1}$, VIDYANAND NANJUNDIAH² and GOPAL PANDE*,1 \\ ${ }^{1}$ Centre for Cellular and Molecular Biology, Hyderabad, India and ${ }^{2}$ Developmental Biology and Genetics Laboratory, \\ Department of Molecular Reproduction, Development and Genetics, Indian Institute of Science, Bangalore, India.
}

\begin{abstract}
Pre-starvation amoebae of Dictyostelium discoideum exhibit random movements. Starved cells aggregate by directed movements (chemotaxis) towards cyclic AMP and differentiate into live spores or dead stalk cells. Many differences between presumptive spore and stalk cells precede differentiation. We have examined whether cell motility-related factors are also among them. Cell speeds and localisation of motility-related signalling molecules were monitored by live cell imaging and immunostaining (a) in nutrient medium during growth, (b) immediately following transfer to starvation medium and (c) in nutrient medium that was re-introduced after a brief period of starvation. Cells moved randomly under all three conditions but mean speeds increased following transfer from nutrient medium to starvation medium; the transition occurred within 15 min. The distribution of speeds in starvation medium was bimodal: about $20 \%$ of the cells moved significantly faster than the remaining $\mathbf{8 0} \%$. The motility-related molecules F-actin, PTEN and PI3 kinase were distributed differently in slow and fast cells. Among starved cells, the calcium content of slower cells was lower than that of the faster cells. All differences reverted within 15 min after restoration of the nutrient medium. The slow/fast distinction was missing in Polysphondylium pallidum, a cellular slime mould that lacks the presumptive stalk and spore cell classes, and in the trishanku (triA) mutant of $D$. discoideum, in which the classes exist but are unstable. The transition from growth to starvation triggers a spontaneous and reversible switch in the distribution of $D$. discoideum cell speeds. Cells whose calcium content is relatively low (known to be presumptive spore cells) move slower than those whose calcium levels are higher (known to be presumptive stalk cells). Slow and fast cells show different distributions of motility-related proteins. The switch is indicative of a bistable mechanism underlying cell motility.
\end{abstract}

KEY WORDS: differentiation, calcium, cytoskeletal organisation, bistability, cellular peristalsis

\section{Introduction}

Multicellular development in the cellular slime moulds (CSMs) is similar in many respects to metazoan development (Gilbert, 2000). But there is one significant difference: the polarised multicellular aggregate or slug, the equivalent of an embryo in the CSMs, forms via the aggregation of spatially separated cells. This feature enables us to focus on the role played by early phenotypic differences between cells in establishing the adult pattern of differentiation. The slug eventually forms a fruiting body consisting of viable spores that are held up by an erect stalk of dead cells. In some CSMs including Dictyostelium discoideum presumptive stalk (pst) and presumptive spore ( $p s p)$ cells are recognisable in the slug by their spatial segregation (Nanjundiah and Saran, 1992), the former being in the anterior and the latter in the posterior. Bonner showed long ago that in $D$. discoideum pst cells moved significantly faster than psp cells, which could be a simple explanation for why they sort out to the front and back of the slug respectively (Bonner, 1952). On the other hand, anterior and posterior cells seem to have comparable motilities in D. mucoroides (Samuel, 1961). Whether a cell adopts a pst or psp fate depends on a number of factors including preaggregation nutritional status, cell cycle phase at starvation and cellular calcium content (Tasaka and Takeuchi,1981; McDonald and Durston,1984; Maeda and Maeda,1973; Azhar et al., 2001; Strmecki et al., 2005; Azhar et al.,1995; Azhar et al., 1996; Baska

Abbreviations used in this paper: CSM, cellular slime mould; PTEN, phosphatase, tensin homologue.

*Address correspondence to: Gopal Pande. CCMB, Hyderabad 500007 India. Phone: +91-40-2719-2605. Fax: +91-40-2716-0591. e-mail: gpande@ ccmb.res.in

Supplementary Material (3 movies, 7 figures and 1 table) for this paper is available at: http://dx.doi.org/10.1387/ijdb.113384ps

Accepted: 22 December 2011. Final, author-corrected PDF published online: 16 January 2012. Edited by: Mieke Van Lijsebettens.

ISSN: Online 1696-3547, Print 0214-6282

(C) 2012 UBC Press

Printed in Spain 
et al., 2000). Strikingly, freshly starved amoebae spontaneously segregate into two classes depending on differences in intracellular calcium, and the classes correspond to the pst and psp states (Azhar et al., 1996; Saran et al., 1994). A bimodal calcium distribution between cells, i.e. a distinction between relatively 'high calcium' and 'low calcium' cells, is most plausibly generated by stochastic variations in phenotype between genetically identical cells, a phenomenon that has been attracting attention lately in other systems (De Falco et al., 2009; King and Freedman, 2009; Losick and Desplan, 2008).

Feeding amoebae of $D$. discoideum move randomly; starved amoebae of $D$. discoideum (Soll et al., 2009) and D.mucoroides exhibit directed chemotactic movements interspersed with random movements (Samuel, 1961). During chemotaxis to an externally perceived spatial gradient of cAMP cells extend pseudopodia towards the cAMP source whereas during random movement pseudopods can be extended in different directions (so that the final direction in which the cell translocates is 'chosen' internally (Soll et al., 2009)). Directed movement is accompanied by a polarised distribution of various signalling molecules. In $D$. discoideum phosphatidylinositol $(3,4,5)$-trisphosphate (PIP3) and CRAC (cytosolic regulator of adenylyl cyclase) lie in the advancing front of a cell; phosphatase, tensin homologue (PTEN) and myosin II heavy chain kinase are found at the back (van Haastert and Devreotes,2004). PIP3 is synthesized by PI3-kinases and degraded by 5-phosphatases such as SHIP and synaptojanin or by the 3-phosphatase tumor suppressor PTEN (lijima et al., 2004). PI3 kinases are found in the front of the cell during the response to a chemoattractant (Sasaki et al., 2007; lijima and Devreotes, 2002; Funamoto et al., 2002; Comer and Parent, 2002). The formation of PIP3 is regulated by the activity of the enzyme phosphatidylinositol 3, 4 (PI-3) kinase (Type I), which catalyses the phosphorylation of phosphatidyl-inositol $(3,4)$-diphosphate (PIP2) following its activation by extracellular stimulation (Sasaki and Firtel, 2006). D. discoideum cells have only a basal level of PI3 kinase activity during the phase of random motility and PI3 kinase activation and cytoplasmic PIP3 accumulation occurs specifically at the site of pseudopod formation (which is rich in F-actin) without any chemoattractant or G-protein involvement (Sasaki et al., 2007, Suire etal., 2005). Local PIP3 patches are associated with increased concentrations of F-actin and pseudopodial extension (Devreotes and Janetopoulos, 2003; Kolsch et al., 2008).

Thus cellular asymmetries of a similar sort underlie both random and directed movement, except that in the latter case there is

Fig. 1. Variation in cell motility of different strains of Dictyostelium discoideum under different nutrient conditions. Average speed of (A) axenically grown cells (AX2), (B) bacterially grown AX2 cells, (C) Polysphondylium pallidum cells and (D) tri $\mathrm{A}^{-}$cells in nutrient medium, in starvation medium and in replaced nutrient medium. ' $n$ ' indicates number of cells tracked under each nutrient condition. ${ }^{*}$ indicates the significant difference $(p<0.05)$ in the speed of cells in starved condition in comparison with the speed of cells in nutrient and replaced medium. a consistent bias provided by the external cue (van Haastert and Devreotes, 2004); the role of the external stimulus appears to bias the choice of a particular direction. It is conceivable that individual cells do this by constraining the spatial distribution of molecules such as the ones mentioned above. The signalling cascade that is activated after binding of CAMP to the cell surface receptor involves a transient increase of cytosolic free calcium concentration, which is necessary for chemotactic orientation and migration (Malchow et al., 1996). Also, an increase in cytosolic $\mathrm{Ca}^{2+}$ concentration enhances membrane ruffling, PI3 kinase activity and F-actin accumulation (Evans and Falke, 2007).

These facts provide the motivation to test the following hypothesis: spontaneously occurring cell to cell variations in the intracellular distribution of molecules related to cell motility are correlated with the bimodal distribution of cellular calcium in pre-aggregation cells and thereby with their post-aggregation fates. If the hypothesis can be validated, it will point to a possible mechanistic link, via motility-related molecules, between differences in intercellular calcium and cell differentiation.

\section{Results}

\section{Increase in motility following onset of starvation}

Cell motility was quantified by recording the movements of axenically grown or bacterially fed $D$. discoideum AX2 cells in one of three different environments: in the normal axenic nutrient (growth) medium, following transfer to non-nutrient 'starvation' medium and after being returned to an axenic nutrient medium. The third regime is the same as the first except that it is preceded by a 30 min exposure to a non-nutrient environment. For making time lapse movies, we provided a gap of $10 \mathrm{~min}$ in each regime before beginning the recordings in order to allow cells adjust to the change. Based on visual observation of time lapse films, cells appeared to move in all possible directions in all three regimes (Supplementary Movie M1). In order to calculate the mean speed of cell motility we recorded the movie for $30 \mathrm{~min}$ in each regime. However, for checking the
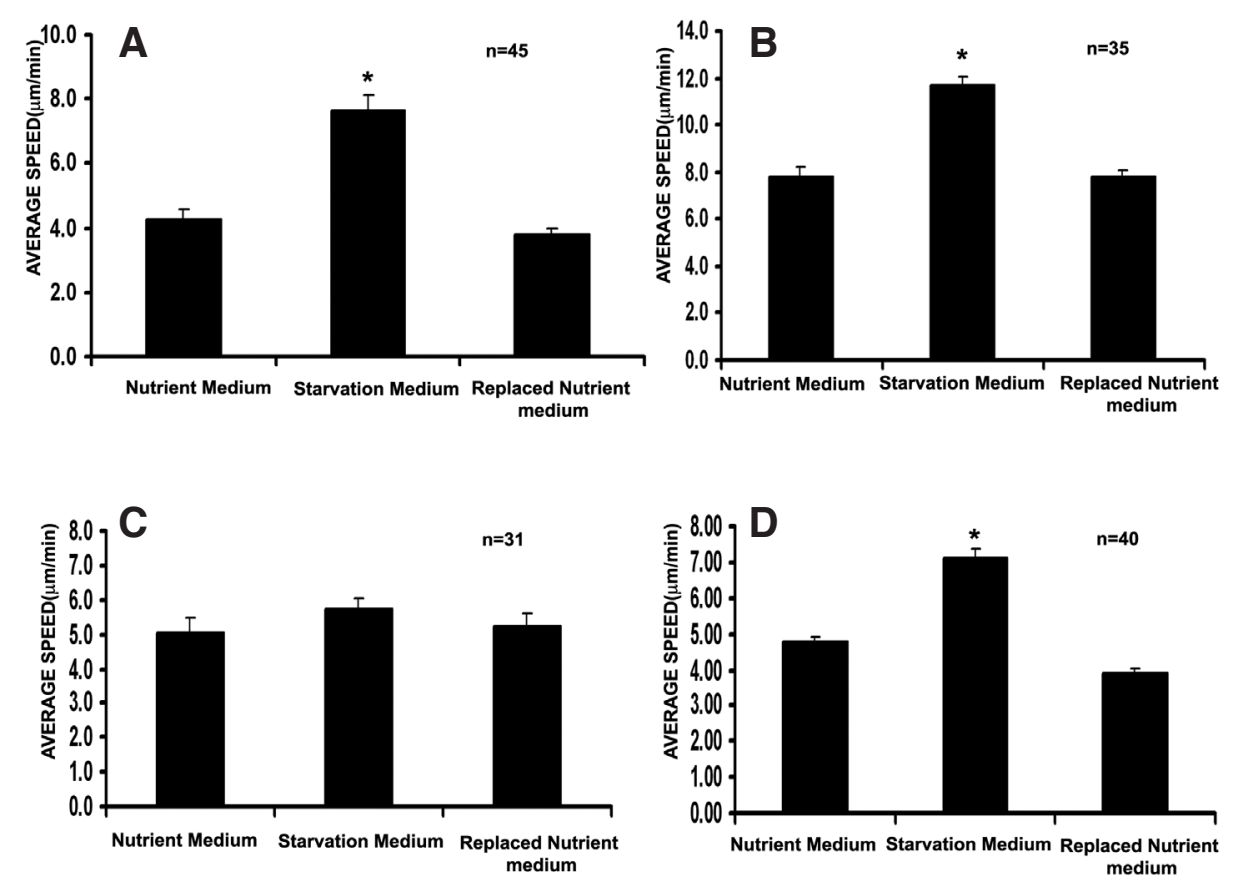
directionality of cell movement we analysed the movement of 10 cells (at higher magnification) in the starvation phase over a 10min period. Our analysis showed that a small fraction, fewer than 4 out of 10 cells, exhibited a wriggling sort of motion and did not appear to move much from their original locations. Examples of these cell types are shown in Supplementary Movie M2.

The mean speed of axenically grown AX2 cells $(n=45)$ over the entire $30 \mathrm{~min}$ of recording was $4 \mu \mathrm{m} / \mathrm{min}$ in nutrient medium. It increased to ca. $7.7 \mu \mathrm{m} / \mathrm{min}$ - that is, by approximately $88 \%$ when nutrients were removed; the speed reverted back to almost the original level within $30 \mathrm{~min}$ after the original nutrient medium was reintroduced (Fig. 1A). Although the speeds of individual cells varied quite a bit (due to the presence of wriggling and directionally moving cells in the same phase), the changes, both increase and decrease, in mean cell speed (represented by 45 cells in each phase) were significant (t-tests, $\mathrm{p}<0.05)$. Thus, axenically grown AX2 cells increase their speed rapidly over a 40 min time interval after starvation induction (10 min gap before recording and $30 \mathrm{~min}$ of recording period) and reduce it back to the original level within the same time interval after replacement of nutrient medium.

Upon further analysis, we found that when the external medium was free of nutrients, cell speeds exhibited a clearly bimodal distribution; but in the nutritional environment under both circumstances the speed distribution was less obviously bimodal and more nearly unimodal (Supplementary Fig. S1 A-C). Based upon the bimodal speed distribution in starvation medium, we could classify cells as Slow or Fast. Slow cells comprised $\sim 81 \%$ of the total number and had speeds ranging from $2-8 \mu \mathrm{m} / \mathrm{min}$. The remaining $19 \%$ of cells could be categorised as Fast; their speeds ranged from 9-16 $\mu \mathrm{m} /$ min. The Fast cell population was absent in the nutritional medium and cell speeds ranged between $1-8 \mu \mathrm{m} / \mathrm{min}$.

As this implies, individual cells changed direction less often and had longer movement tracks under starvation; however, a few still showed the wriggling type of locomotion (Supplementary Fig. S2 A-C). Fast cells showed longer tracks in comparison to slow cells (Supplementary Fig. S2 D-E). In order to statistically analyse the displacement of cells over $10 \mathrm{~min}$, we calculated the mean square displacement of 10 cells in each condition. The distribution of individual cell displacement in each condition also showed that cell motility in every condition was random. (Supplementary Fig. S3 A-C, Supplementary Table 1). The motility of AX2 cells fed with Klebsiella aerogenes was also checked by the same method. In presence of bacteria, AX2 cells moved about twice as fast (Fig.1B) than when they were grown in axenic medium. Upon starvation there was a $75 \%$ increase in the speed of these cells, which reduced significantly $(p<0.05)$ when bacteria were reintroduced in the medium (Fig. 1B). Thus Dictyostelium discoideum amoebae moved significantly more slowly under conditions favouring growth than when starved (Van Haastert and Bosgraaf, 2009); a similar observation was made by Samuel in his study of cell motility in $D$. mucoroides(Samuel, 1961). In contrast, Polysphondylium pallidum amoebae did not show any significant change in their speeds when switched between nutrient-rich and starvation media (Fig. 1C); their total motility tracks were relatively short and the average cell speed was about 5-6 $\mu \mathrm{m} / \mathrm{min}$ under all three conditions (Supplementary Fig. S1 D-F). Also, in comparison to $D$. discoideum, the pseudopodia formed by $P$. pallidum cells were less prominent. The mean speed of triA mutant cells (Fig. 1D) in nutrient-rich or starvation media was similar to that of AX2 cells but, unlike AX2, triA-cells did not show a bimodal distribution of speeds in starvation medium
(Supplementary Fig.S1 G-I). The range of cell speeds reported here overlaps significantly with the developmental stage-dependent but unimodal distribution (as in P. pallidum and tri $A^{-}$) that Samuel found in D. mucoroides (Samuel, 1961).

\section{Intracellular calcium and cell speed}

When freshly starved axenically grown AX2 cells were analysed in a flow cytometer after FLUO-3 labelling, about $85 \%$ of the cells
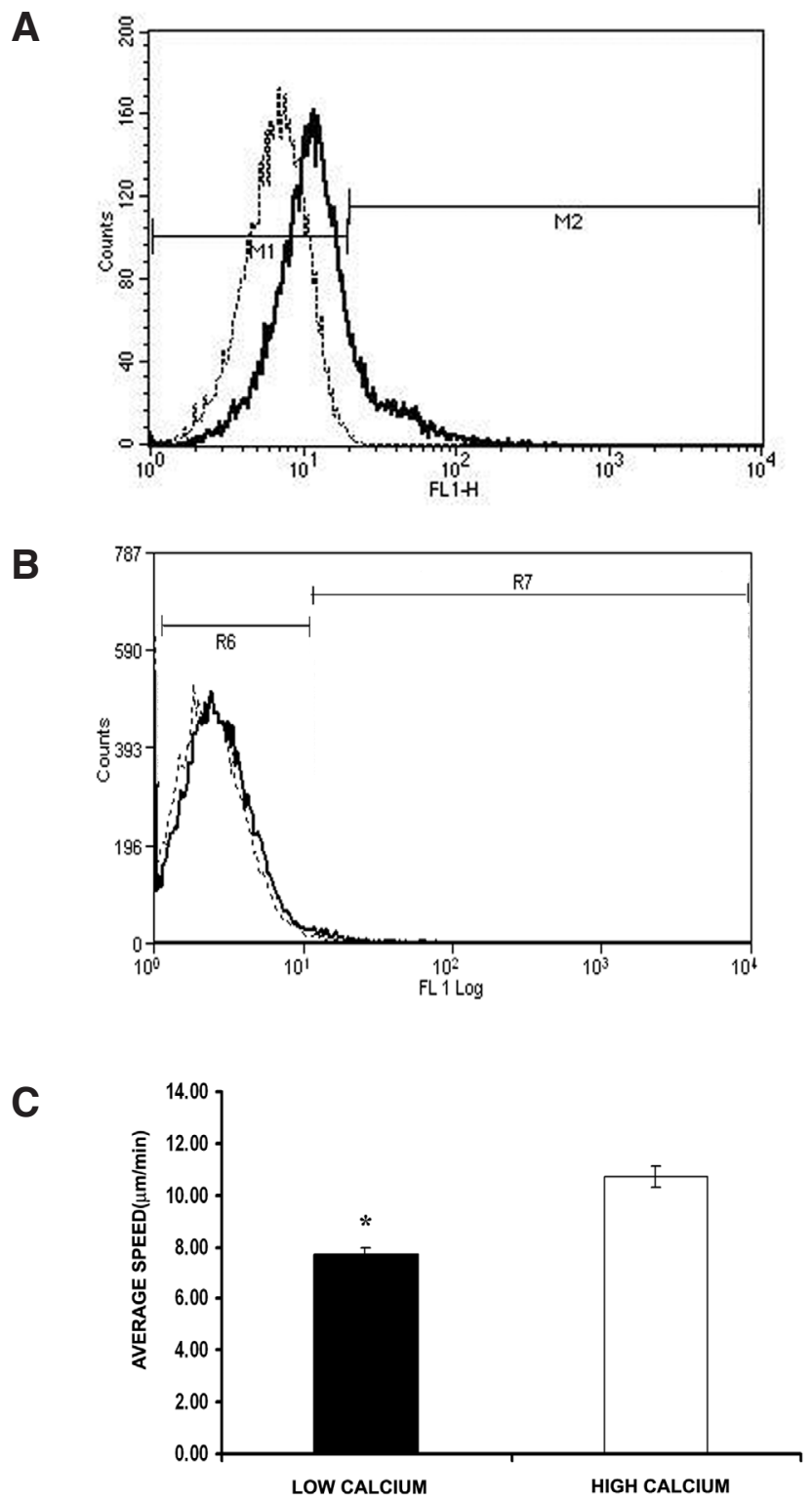

Fig. 2. Intracellular calcium content and speed of cell locomotion. Freshly starved AX2 cells were, labeled with $\mathrm{Ca}^{2+}$ sensitive dye Fluo-3 and processed for fluorescence based cell sorting for separating High and Low calcium containing cells. (A) The overlapping histograms of the Fluo-3 labeled and sorted cells for High and Low calcium content during starvation. (B) The overlapping histograms of the Fluo-3 labeled (solid line) and unlabeled (dotted line) cells under nutrient conditions. (C) Average speed of AX2 cells $(n=30)$ obtained after sorting for High and Low calcium content in $(B) .{ }^{*}$ indicates the significant difference $(p<0.05)$ in the speed of High and Low calcium containing cells in starved condition. 
showed fluorescence levels similar to the background (auto fluorescence) and the remaining 15\% showed increased fluorescence (Fig. 2A) but cells in nutrient condition did not show any increase in fluorescence levels (Fig. 2B). These starved FLUO-3 labeled cells were designated as Low and High $\mathrm{Ca}^{2+}$ cells respectively, and after FACS sorting the motilities of the sorted Low and High calcium cells were monitored by time lapse microscopy for $30 \mathrm{~min}$ in starvation medium as described in Materials and Methods. The mean speed of the sorted cells was calculated from the pooled data of 3 independent experiments and for the High $\mathrm{Ca}^{2+}$ cells it was about $11 \mu \mathrm{m} / \mathrm{min}$ (with variation range of $8-15 \mu \mathrm{m} / \mathrm{min}$,) and that of the Low $\mathrm{Ca}^{2+}$ cells, about $8 \mu \mathrm{m} / \mathrm{min}$ (with a variation range of 3-11 $\mu \mathrm{m})$. This difference in the mean speeds of the two cell types was significant ( $p<0.05$; see Fig. $2 C)$. Supplementary Fig. S4 A-C

A

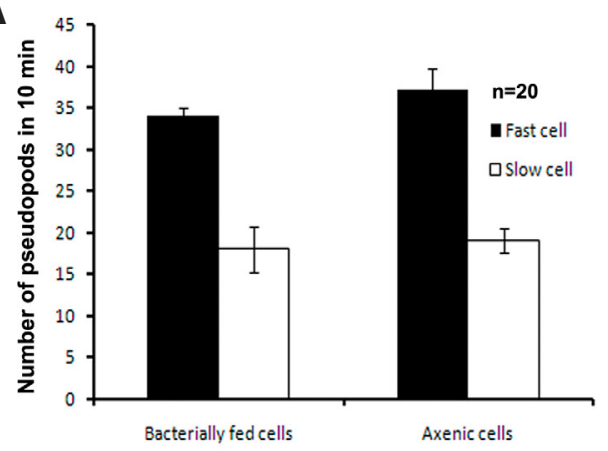

C Nutrient medium

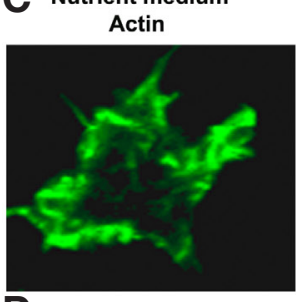

D Actin

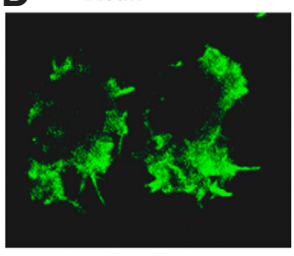

E Starvation

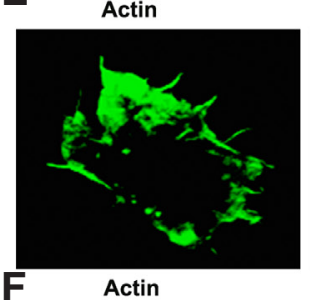

F
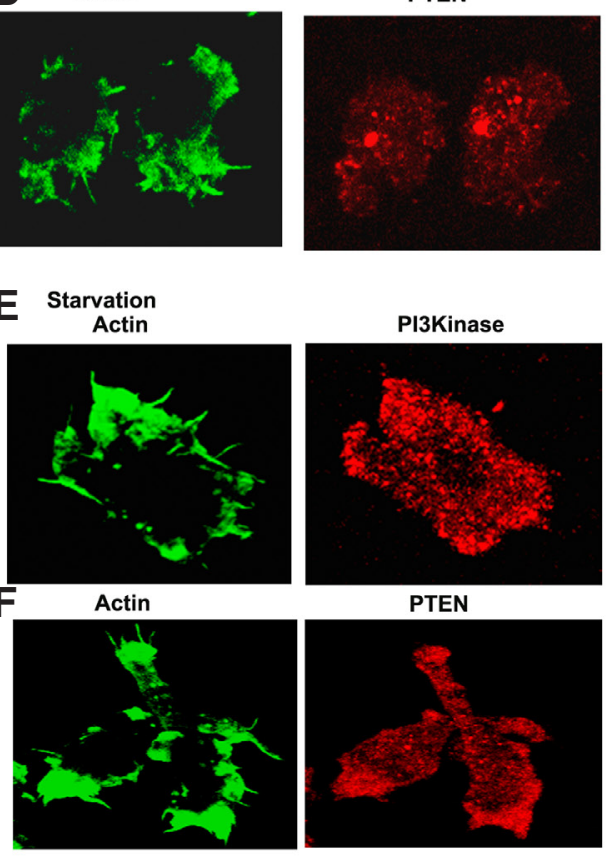

B
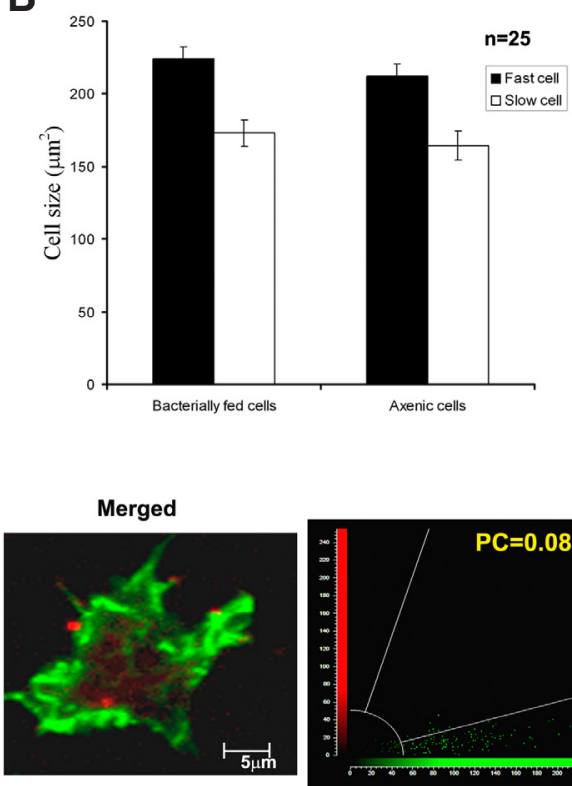

Merged
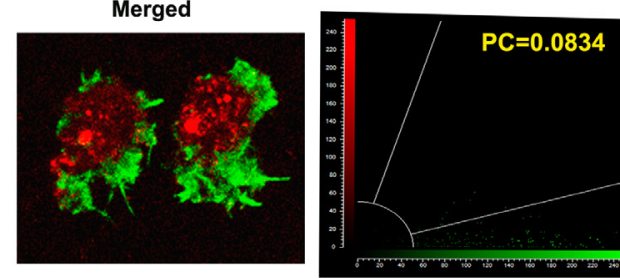
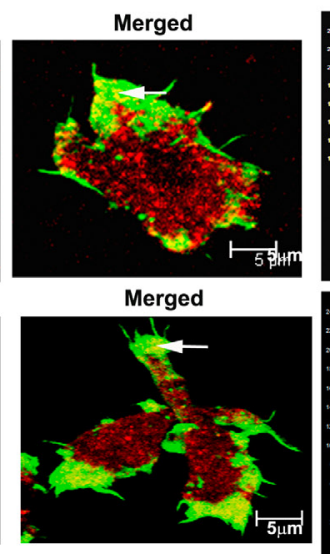

shows the Fluo3 labeled and unlabeled cells. Tracks of Fluo3 labeled cells (Track No: 1-4) were longer-these cells showed faster motility and unlabeled cells (Track No: 5-8) were shorter and showed slow or wriggling type of locomotion (Supplementary Fig. S4 D).

\section{Formation of pseudopodia in Slow and Fast cells}

We measured the total number of pseudopodia formed by each cell over 10min and the areas of individual cells with the help of the Axiovision software (Shu et al., 2010) Per unit time, Fast cells made more pseudopodia ( 35 per cell) than Slow cells $(\sim 17$ per cell) $(n=15, p<0.05$. Fast cells were also larger (mean area $=215$ $\mathrm{m}^{2}$ ) than Slow cells (mean area $=170 \mathrm{~m}^{2}$ ), both in axenic and bacterial growth media $(n=25, p<0.05$; compare numbers in Fig. $3 \mathrm{~A}, \mathrm{~B})$. In both environments the more linearly moving cells made pseudopodia towards the leading edge whereas cells that moved in a wriggling manner formed pseudopodia in all directions (Supplementary Movie M3). On average, Fast cells formed more pseudopods per turn $(\sim 17)$ than Slow cells $(\sim 10 ; n=15$, Supplementary Fig. S5 A,B,C).

\section{Localisation of motility-specific signal- ling molecules}

Three proteins that play an important role in motility and chemotaxis (Sasaki et al., 2007; Funamoto et al., 2002), namely F-actin, PI3kinase and PTEN, were

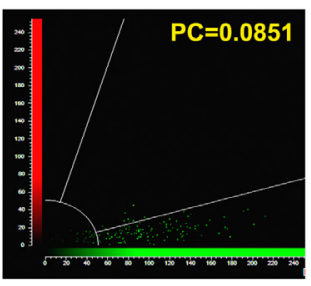

Fig. 3. Variation in number of pseudopodia and cell size, and distribution of actin / PI3 kinase and actin / PTEN molecules in AX2 cells under different nutrient conditions. (A) Number of pseudopodia formed in $10 \mathrm{~min}$ duration in axenically grown D. discoideum and in bacterially fed fastand slow cells. (B) Correlation of cell size $\left(\mu \mathrm{m}^{2}\right)$ between fast and slow cells in axenic cells and in bacterially fed D. discoideum cells. Distribution of F-actin (green) and P/3 kinase (red) is shown in AX2 cells in nutrient medium (C) and distribution of F-actin (green) and PTEN (red) in AX2 cells in nutrient medium (D). Bar, $5 \mu \mathrm{m}$. Distribution of F-actin (green) and PI3 kinase (red) is shown in AX2 cells after starvation (E) and distribution of F-actin (green) and PTEN (red) in AX2 cells after starvation (F). Bars, $5 \mu \mathrm{m}$. The leading edge (marked as 'LE') and the pseudopods (marked as ' $P$ ') has been shown in the figure. Fluorescence quantification of Actin/PI3kinase and Actin/PTEN stained cells during different nutrient conditions. Quantification of co localization of Actin/PI3kinase in D.discoideum cells in Nutrient medium(C) (Pearson's correlation 0.0851) and Quantification of co localization of Actin/PTEN in D. discoideum cells in Nutrient medium (D) (Pearson's correlation 0.0834). Quantification of co localization of Actin/PI3kinase in D.discoideum cells during starvation (E) (Pearson's correlation 0.1269) and Quantification of co localization of Actin/PTEN in D. discoideum cells during starvation (F) (PC, Pearson's correlation $=0.7173$ ) . 
monitored in stained cells. Representative images based on immunofluorescence of conjugated antibodies are shown in Fig. 3. F-actin showed comparable spatial distributions under all three conditions but there were minor differences. In nutrient medium, cells appeared well spread and most cells, as represented by the single cell shown in Fig.3, exhibited a dense localisation of F-actin in the leading part and a faint distribution in the trailing parts of a pseudopodium or in the rest of the cytoplasm. In the same cells a diffuse spread of PI3kinase was visible everywhere in the cytoplasm (Fig. 3C) and PTEN was distributed in large endosomal vesicles (Fig. 3D). In starvation medium there was a dense accumulation of F-actin in the leading edge of a pseudopodium that extended to the cell's anterior margin; its presence in the cytoplasm was negligible. PI3kinase fluorescence was localised in a number of small vesicles (Fig. 3E) and PTEN was seen mainly in pseudopodia, especially near the membrane, where it was associated with F-actin (Fig. 3F). When nutrient medium was restored after 30min in starvation medium, the distribution of $\mathrm{F}$-actin, PI3Kinase and PTEN became similar to that shown in Fig. $3 \mathrm{C}$ and $D$ respectively.

We analysed the co-localization of F-actin with PI3Kinase and PTEN by image analysis software using Pearson's Coefficient values as the indicator of co-localization. The analysis confirmed what was apparent to the eye: F-actin and PI3kinase were not co-localised in the nutrient media but their colocalization levels increased during starvation because Pearson values in starved cells were higher than in nutrient media (compare Fig. 3C and E). Microscopically also we could notice small spots of yellow fluorescence in pseudopodia in starved cells which not present in cells kept in nutrient media. In the case of PTEN co-localization with $F$-actin the increase in starvation medium was much more (compare Fig. 3 D,F). The PTEN activity in starved cells also appeared to be higher because when cells were in starvation medium PIP2, a product of PTEN activity, was also colocalised with F-actin at the edges of the pseudopods (Supplementary Fig. S6). The localisation of these molecules agrees with what has been reported earlier by others (van Haastert and Devreotes, 2004). the co localization of molecules.

\section{Polarisation and motility}

We measured both anterior-posterior (AP) and transverse cell dimensions under starvation and nutrient conditions as depicted in Supplementary Fig. 7. The AP axis of cells in starvation medium was longer than that of cells under nutrient conditions either before or after starvation; this means that as expected, cells become elongated in the direction of migration after transfer to starvation medium (Supplementary Fig. S7 A-G).

Actin, PTEN and PI3kinase localization was studied by immunofluorescence in Low and High $\mathrm{Ca}^{2+}$ cells (i.e., Slow and Fast cells respectively). In Slow cells F-actin was localized in the cytoplasm
A

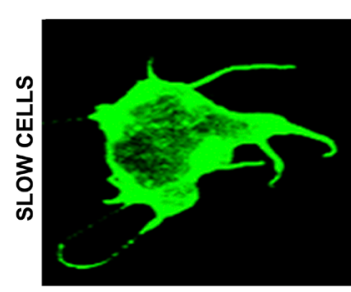

B

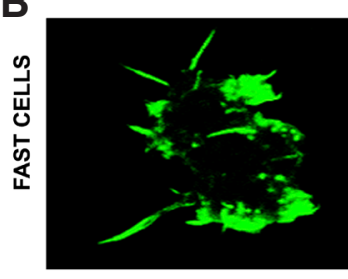

C

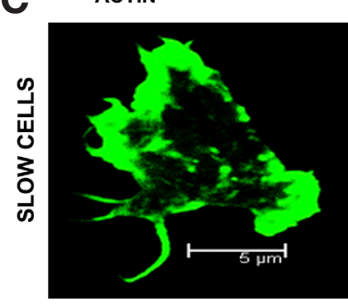

D

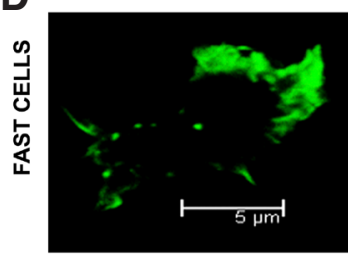

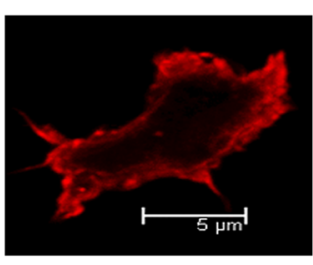

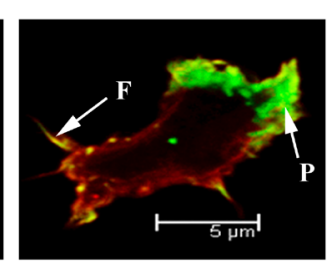

MERGED
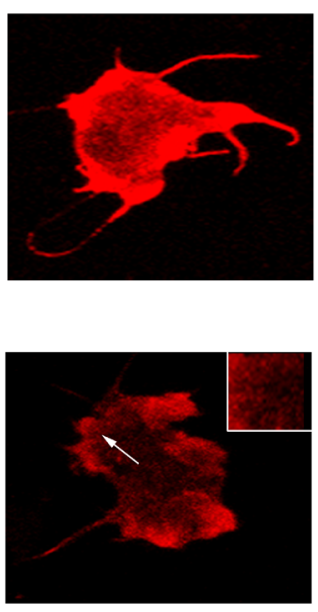

PTEN
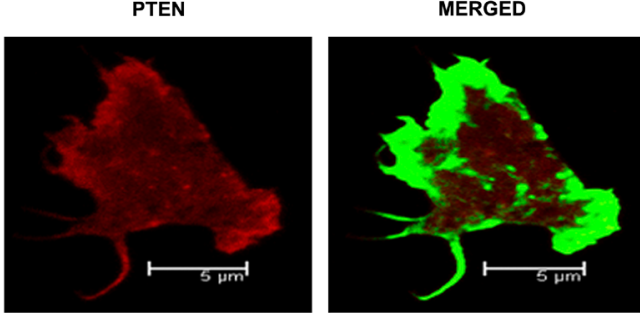

Pearson's Correlation 0.525 *

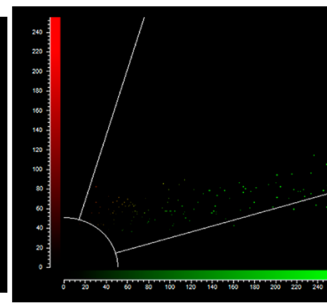

Pearson's Correlation 0.8425 *

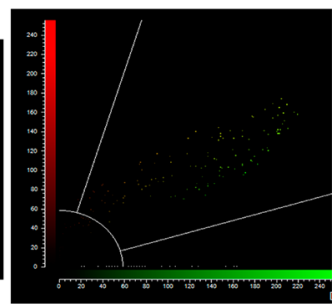

Fig. 4. Distribution of F-actin, PI3 kinase and PTEN in High and Low intracellular $\mathrm{Ca}^{2+}$ containing $\mathrm{AX2}$ cells. AX2 cells in starvation medium were labeled with Fluo-3, sorted through FACS for High and Low Ca ${ }^{2+}$ containing cells and stained for F-actin, PI3 kinase and PTEN. (A,B) Distribution of F-actin (green) and PI3 kinase (red) in Low Ca $a^{2+}$ cells $(A)$ and in High Ca ${ }^{2+}$ cells (B). (C,D) Distribution of F-actin (green) and PTEN (red) in Low $\mathrm{Ca}^{2+}$ cells (C) and in High $\mathrm{Ca}^{2+}$ cells (D). All bars represent $5 \mu \mathrm{m}$. The pseudopods (marked as ' $\mathrm{P}^{\prime}$ ) and filopodia (marked as ' $F$ ') has been shown in the figure. Pixel analysis of Actin/PI3Kinase and Actin/PTEN stained Slow and Fast cells. Quantification of co localization of Actin/PI3Kinase stained Slow cell (A) (Pearson's correlation 0.87) and Fast cell (B) (Pearson's correlation 0.732) and Actin/PTEN stained Slow cell (C) (Pearson's correlation), Fast cell (D) (Pearson's correlation 0.8425). Numbers with ${ }^{*}$ indicate significant difference $(p<0.05)$ in 
and association with the plasma membrane edges (Fig. 4 A,C). In the Fast cells (10 cells each), actin was localised primarily in the pseudopods (Fig. 4 B,D). More filopodial extensions of actin rich cytoplasm were formed in Slow cells correlating with the lesser motility, while Fast cells showed fewer filopodia and more pseudopodia correlating with their fast motility. Samuel found a similar correlation between number of pseudopods and speed of movement in $D$. mucoroides, but no difference in mean rates of locomotion between amoebae isolated from the front and back of slugs (Samuel, 1961). In Slow cells both PI3kinase and PTEN were present predominantly in the pseudopods and very diffusely in the cytoplasm (Fig. 4 A,C). In Fast cells PI3 kinase was primarily localised in the leading edge pseudopods and some amounts could be seen in cytoplasmic vesicles (Fig. 4B) see inset for vesicular localization) whereas PTEN was seen more towards the pseudopodial extensions and the sides of the cell (Fig. 4D).

\section{Intracellular nutrient levels and motility}

It is known that when starved cells that were grown in axenic medium supplemented with $86 \mathrm{mM}$ glucose ( $\mathrm{G}^{+}$cells) are mixed with starved cells that were grown without added glucose (G-cells), the $\mathrm{G}^{+}$cells show a tendency to form spores whereas $\mathrm{G}^{-}$cells tend to form part of the stalk (Leach et al., 1973). We asked the question could this be related to the sorting out caused by motility differ-
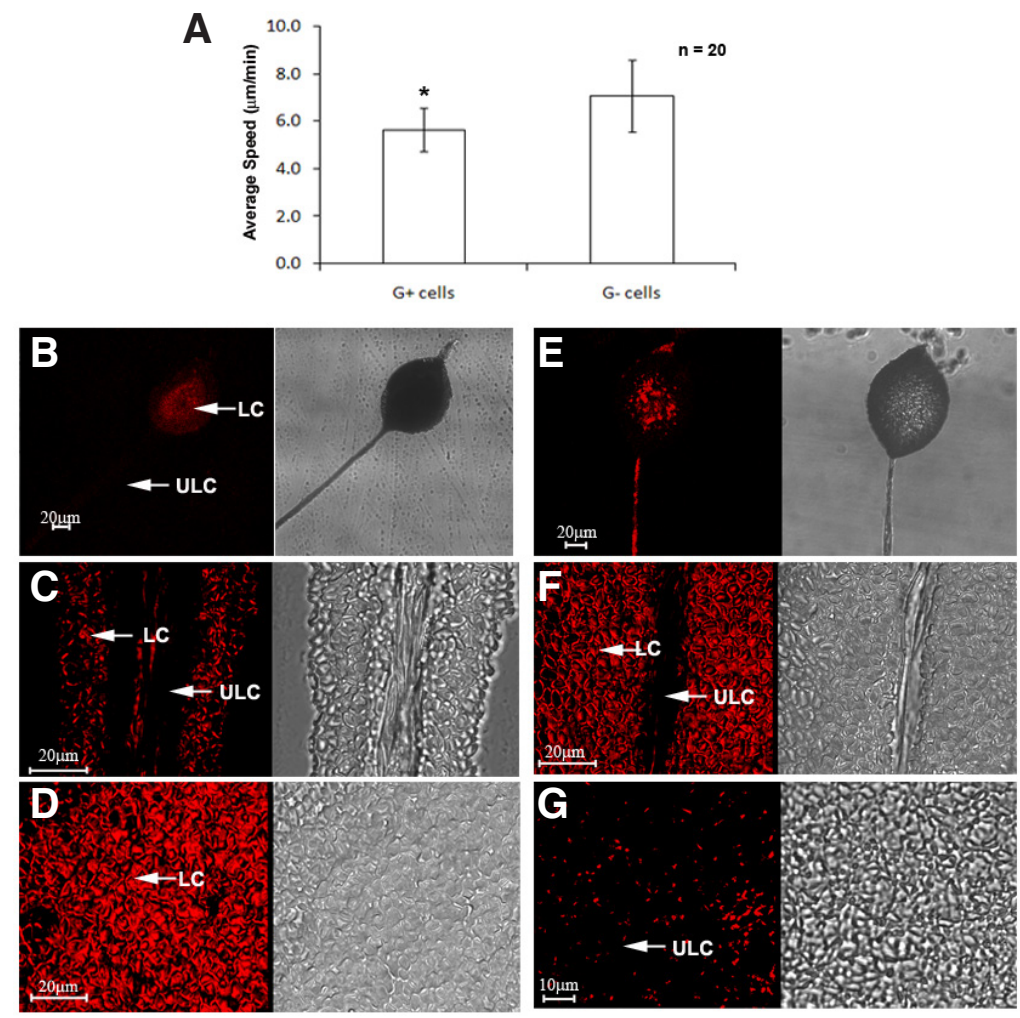

Fig. 5. Reconstitution of Glucose ${ }^{+}$and Glucose- cells using DID labeled cells. Average speed of Glucose ${ }^{+}$(Slow cells) and Glucose- (Fast cells) cells (A), ' $n$ ' represents the number of cells and '*' represents the significance of deviation. The labeled $G^{+}$(LC-shown by an white arrow) and unlabeled $G^{-}$cells (ULC-shown by an white arrow) were mixed in equal proportions and (B) shows the D.discoideum fruiting body, where the unlabeled $G^{-}$cells form the stalk cells and labeled $G^{+}$cells form the spore head. (C,D) The spore head and the stalk cells. (E,F,G) The fruiting body, spore head and stalk cells of the labeled $G^{-}$and unlabeled $G^{+}$cells. ences? We found that the mean speed $(7.0 \mu \mathrm{m} / \mathrm{min})$ of $\mathrm{G}^{-}{ }^{-} \mathrm{AX} 2$ cells was significantly higher $(p<0.05)$ than that of $G^{+}$cells $(5.7 \mu \mathrm{m} / \mathrm{min})$ (Fig. 5A). When starved $\mathrm{G}^{+}$cells were labelled with $\mathrm{DiD}$, mixed in equal proportions with $\mathrm{G}$ - cells that were unlabelled and incubated for further development, in the fruiting bodies formed $(n=8$ and the representative figure shown in Fig. 5) the stalk mostly contained Slow (unlabelled, G-) cells whereas the spore mass mainly consisted of Fast (labelled, $\mathrm{G}^{+}$) cells (Fig. 5 B-D). The distribution of fluorescence was exactly the opposite when labelled $G$ - cells were mixed with unlabelled $\mathrm{G}^{+}$cells; once again Fast (labelled, $\mathrm{G}^{-}$) cells were in the stalk and Slow (unlabelled, $\mathrm{G}^{+}$) cells were in the spore head (Fig. 5 E-G).

\section{Discussion}

Among the many differences between amoebae that are correlated with terminal differentiation in the cellular slime moulds (reviewed in (Nanjundiah and Saran, 1992)), those that relate to motility and chemotaxis are especially interesting. Presumptive stalk cells that are dissociated from $D$. discoideum slugs move faster than presumptive spore cells, and the difference in speeds can plausibly be related to their abilities to sort out to their normal positions in the slug front and back respectively (Bonner, 1952). Using the same $\mathrm{G} / \mathrm{G}^{+}$technique as us, Inouye and Takeuchi were able to trace the difference in speeds in starved cells to about $8 \mathrm{hr}$ after starvation and just before the formation of aggregation streams (Inouye and Takeuchi, 1982). However, we are able to identify two phenotypic (speed) classes in starved cells. Both bimodality and the increase in average speed of movement upon starvation can be seen essentially immediately after the withdrawal of nutrients. In the present study, using AX2 cells, we have shown that during early stages of nutritional starvation there is a simultaneous appearance of a bimodal distribution of cell phenotypes with respect to (a) relative calcium content (High or Low) and (b) motility (Fast or Slow). Based on our observations of the developmental fates of DiD-labelled $\mathrm{G}^{+}$vs. $\mathrm{G}^{-}$and Slow vs. Fast cells, we argue that cells with a relatively high level of calcium (which are known from previous work to be presumptive stalk cells (Azhar et al., 1995; Azhar et al., 1996; Baskaret al., 2000)) are by and large the same as Fast cells.

\section{Bimodal distribution of cell speed and intracellular calcium are early indicators of cell fate}

Our data show that as a whole starved AX2 cells moved faster and exhibited elevated intracellular $\mathrm{Ca}^{2+}$ in comparison to cells in nutrient medium (compare Figs. $1 \mathrm{~A}$ and $2 \mathrm{~A}$ ). In both cases the distributions that resulted were visibly bimodal within 10 min of the induction of starvation. This divides the population of freshly starved cells into two overlapping classes; in our study about $19 \%$ belonged to the Fast category and about $15 \%$ showed a significant increase in cellular calcium (compare the patterns in Supplementary Fig. S1 B and Fig. 2A). The higher frequency of random pseudopod formation (Fig. 3A) would lead to rapid movement and could be helpful as a food-seeking strategy in Fast cells soon after the onset of starvation (Ridley et al., 2003; Li et al., 2008; Vicente-Manzanares 
et al., 2005; Bosgraaf and Van Haastert, 2009).

A bimodal distribution of speeds was not discernible in freshly starved Polysphondylium pallidum (Supplementary Fig. S1 E) or in the triA mutant of $D$. discoideum (though triA- cells speed up after starvation (Fig 1D and Supplementary Fig 1H)). Interestingly, $P$. pallidum lacks a prespore-prestalk distinction and its intracellular calcium is distributed unimodally, not bimodally (Azhar et al., 1995); the prestalk-prespore distinction exists in triA cells but the specification of cell types is unstable (Jaiswal et al., 2006). These observations strengthen our belief that the correlation between two speed classes and bimodal calcium distribution on the one hand, and early cell fate bias on the other, is real. It is unclear whether Samuel's observation of no distinction in speeds between pst and psp cells of $D$. mucoroides (Samuel, 1961) can be ascribed to a different way of computing speeds or points to a more basic difference between $D$. discoideum and $D$. mucoroides.

\section{Spatial differences of signalling molecules within motile cells}

Among several other determinants, the reciprocally acting enzymes PI3 kinase and PTEN act in consonance to regulate the levels of PIP3 and PIP2 in Dictyostelium (Suire et al., 2005). The distribution of $\mathrm{F}$-actin plays a critical role in generating the driving force for forming the membrane protrusions and pseudopodia at the leading edges of the cells (Fraley et al., 2005). The size, number, rapid formation and assembly/disassembly of pseudopodia determine the motility of cells, and the association of $\alpha$ actinin and PIP2 in this process has been well documented (Fraley et al., 2005).

We have immuno-localised PI3kinase in Fast and Slow cells by confocal microscopy and image analysis after using a fluorescently tagged monoclonal antibody (Santa Cruz Biotechnology Inc.) that cross-reacts with the Dictyostelium enzyme. PI3 kinase was distributed mainly in the presumptive pseudopods in Fast cells but throughout the cell in Slow cells (representative cells shown in Fig. 4 ), both classes being made up of freshly starved and randomly moving cells. In contrast, cells that were actively chemotactic and moving in a particular direction showed PI3 kinase localization in the leading edge and sides of the cell (Funamoto et al., 2002).

The role of PTEN in D. discoideum cell motility is well described. pten-/- cells express defects in motility and form pseudopodia at random locations (Wessels et al., 2007). PTEN localisation in our experiments was done in the same way as for PI3kinase, and the results show that under nutrient rich conditions PTEN molecules were localised in the endosomal vesicles (Fig. 3D). The accumulation of endosomal vesicles indicates that they are not being recycled to the membrane or to other organelles. On the other hand during early starvation, intense PTEN staining could be seen in the cytoplasm and at the posterior pseudopods and there was no vesicularisation of fluorescence, implying that starvation of cells initiated recycling of PTEN from the cytoplasm to the lateral membrane. According to earlier reports, in motile chemotaxing cells much of the PTEN delocalises from the leading edge and it gets distributed mostly on the lateral membranes (Funamoto et al., 2002; Wessels et al., 2007). The functional consequence of this in the starved cells could be dephosphorylation of PIP3 (leading to the formation of PIP2) and turnover of focal adhesions required for the rapid movement of the cell.

\section{Correlation of intracellular $\mathrm{Ca}^{2+}$ and signalling molecules}

We found a strong correlation between $\mathrm{High} \mathrm{Ca}^{2+}$ cells and Fast cells; based on our observations we propose that these two properties belong to the same cells. The distribution pattern of motility regulating molecules such as F-actin, PTEN and PI3kinase (Fig. 4 $A, B$ and $C, D)$ in Fast and Slow cells could be the reason why High $\mathrm{Ca}^{2+}$ cells move faster. These molecules are also known to assist the formation of pseudopodia, which are similar to the lamellipodial extensions of mammalian cells (Small et al., 2002; Giannone et al., 2004; Bukharova et al., 2005; Medalia et al., 2007), and in our experiments Fast AX2 cells made more pseudopods where actin localisation was high. This relationship between cellular calcium levels, redistribution of the cell motility related molecules and cell speed could have emerged due to the process of "cellular peristalsis" proposed by Jaffe (Jaffe, 2010) in which waves of increased calcium in cells assist in the segregation of cellular components towards the lateral side of the cell and thereby modulate the velocity of cell movement. In our system Fast cells contain high calcium and seem to segregate PTEN molecules laterally in the cell.

The hypothesis under test was that levels of intracellular calcium and distribution of cell motility related molecular apparatus during the early stages of starvation are jointly correlated with cell fate in D. discoideum. Our results, especially with cell speeds of $\mathrm{G}^{+}$and $\mathrm{G}$ cells and the fluorescence microscopy of motility related molecules in the pseudopodia of Slow (in nutrient media) and Fast (starved) AX2 cells, demonstrate that such a correlation does exist. These results are further supported by the fact that in other Dictyostelids, that do not show a clear distinction of spore and stalk cells or where differences in cellular calcium are not clear we do not see differences in cell speed at starvation time. Our results impel us to further investigate how the intracellular calcium levels, a factor already known to be correlated with cell fate, affect the distribution of motility related molecules, a determinant of cell speed in starved cells and cells in nutrient medium.

The rapidity of the onset of a bimodal distribution of cell speeds (and its equally rapid disappearance when nutrients are restored) strongly suggests that what we are seeing is a reversible dynamical transition triggered by the external environment. The transition is from a uniform steady state (in nutrient medium, and consisting of a single class of slow moving cells) to a non-uniform steady state (in starvation medium, and consisting of two classes of cells, slow- and fast-moving). The non-uniform steady state is indicative of an underlying bistability in the dynamics caused by negative feedback between two pathways. It demonstrates that the motility phenotype of $D$. discoideum amoebae is plastic. There is a precedent; tumour cells exhibit a form of phenotypic plasticity similar to this by switching between two pathways that inhibit each other (Sanz-Moreno et al., 2008) The outcome is either a round cellular morphology with bleb-driven slow movement (due to Rho/ ROCK-induced actomyosin contractions) or an elongated morphology and rapid, leading-edge movement (driven by Rac-induced actin polymerisation). However, in $D$. discoideum, studies on cell motility have so far yielded no genetic or biochemical feature that can be correlated either with the bimodality seen by us or with the subsequent bimodal developmental fate of cells (Li et al., 2008).

\section{Conclusion}

Immediately (within 15-30 min) after starvation, amoebae of $D$. discoideum segregate into two motility classes. Relatively Fast amoebae differ from Slow amoebae in the spatial organisation of 
their motility-related proteins and in having higher calcium levels. The two classes are biased to differentiate into stalk and spore cells respectively. This is the first report on the induction of differences. We suggest that the classes originate via a spontaneous transition in cytoskeletal organisation from a uniform to a bistable steady state.

\section{Materials and Methods}

\section{Cell culture}

Dictyostelium discoideum (AX2), triA- and Polysphondylium pallidum (Dicty Stock Center Cat. No. PN500 (0236808)) spores were cultured on an evenly spread suspension of Klebsiella aerogenes on separate SM/5 agar (plates made with Glucose $(2 \mathrm{~g})$, Peptone $(2 \mathrm{~g})$, yeast extract $(0.2 \mathrm{~g})$, agar $(12 \mathrm{~g}), \mathrm{KH}_{2} \mathrm{PO}_{4}(0.44 \mathrm{~g}), \mathrm{K}_{2} \mathrm{HPO}_{4}(.0134 \mathrm{~g})$ and $\mathrm{MgSO}_{4} .7 \mathrm{H}_{2} \mathrm{O}(0.2 \mathrm{~g})$ in 1 liter of water). All plates were maintained at $22^{\circ} \mathrm{C}$ for spore germination. The spores from the fruiting bodies were inoculated in $\mathrm{HL}-5$ medium (made with Bacto peptone (10g), yeast extract $(5 \mathrm{~g}), \mathrm{Na}_{2} \mathrm{HPO}_{4}(0.34 \mathrm{~g}), \mathrm{KH}_{2} \mathrm{PO}_{4}(0.35 \mathrm{~g})$, glucose $(10 \mathrm{~g})$, in 1 liter water, final $\mathrm{pH}$ 6.4- 6.6) along with Penicillin and Streptomycin (1X) and incubated at $22^{\circ} \mathrm{C}$ for spore germination. The germinating cells were grown till confluency, sub cultured and later used for further experiments. Axenic AX2, tri $A^{-}$and Polysphondylium pallidum cells were grown in HL-5 medium and bacterially fed AX2 cells were grown in $\mathrm{HL}-5$ medium containing Klebsiella aerogenes. During the starvation period cells were maintained by shaking in $\mathrm{KK} 2$ buffer $\left(\mathrm{KH}_{2} \mathrm{PO}_{4}(2.2 \mathrm{~g}), \mathrm{K}_{2} \mathrm{HPO}_{4}\right.$ $(0.67 \mathrm{~g}), \mathrm{pH} 6.4-6.6)$ at $22^{\circ} \mathrm{C}$. The $\mathrm{G}^{-}$cells were grown in the same $\mathrm{HL}-5$ as described above without glucose.

\section{Reagents and antibodies}

D-Glucose, peptone, yeast extract, agar, $\mathrm{KH}_{2} \mathrm{PO}_{4}, \mathrm{~K}_{2} \mathrm{HPO}_{4}, \mathrm{MgSO}_{4} .7 \mathrm{H}_{2} \mathrm{O}$, $\mathrm{Na}_{2} \mathrm{HPO}_{4}$ were all procured from Sigma. Bacto peptone was procured from BD Biosciences. PI3 kinase p85amonoclonal antibody was procured from Santa Cruz Biotechnology Inc., PTEN monoclonal antibody was from Chemicon International. The activity of these antibodies which were made against mammalian molecules, was tested by doing a western blot against Dictyostelium enzymes using the whole cell lysates of axenically grown AX2 cells. Alexafluor 488 Phalloidin, Fluo-3 and Pluronic F-127 were from Invitrogen. Cy3 conjugated antimouse antibody was from Amersham Biosciences. Lab-Tek II chambered cover glass was obtained from Nalge Nunc International (Naperville, IL). Fluorescein anti PI $(4,5) P 2$ IgM was obtained from Echelon Biosciences. Vybrant DiD cell-labeling solution (V-22887) was procured from Molecular probes.

\section{Live cell imaging}

Dictyostelium discoideum cells were grown axenically in HL5 medium for $22-48$ hours at $22^{\circ} \mathrm{C}$. Approximately $1 \times 10^{5}$ axenically grown cells were plated in 2-welled chambered cover glass. The chambered cover glass was placed on the motorized stage of a computer controlled epifluorescence microscope (Zeiss Axiovert 200M) equipped with a CCD camera and maintained at temperature between $20-22^{\circ} \mathrm{C}$. A $20 \mathrm{X}$ Phase contrast objective (Ph2) lens and Zeiss Axiovision software (Version 4.3) were used to capture the cell images as single frames; time-lapse movies of the motile cells in nutrient medium (HL5) were prepared for 30 min with a 10 second interval between the frame. After 30 min the HL- 5 media was pipetted out and KK2 buffer was added to the cells without disturbing them. After allowing the cells and the buffer to settle for about $10 \mathrm{~min}$, which gave time to the cells to adjust to the change in the osmolarity of the medium, a movie for the same cells as earlier was prepared exactly in the same way as described above. After 30 min KK2 buffer was pipetted out and nutrient medium was added back on to the cells. After giving about $10 \mathrm{~min}$ time for cells and the medium to settle, imaging of the same cells was continued further for 30 min. Exactly the same procedure was followed for imaging the motility of Polysphondylium pallidum and triA- cells. For the bacterially fed AX2 cells the first recording of $30 \mathrm{~min}$ was done in the presence of live Klebsiella after which the supernatant medium was carefully removed and the cells were washed twice with $1 \mathrm{ml}$ of KK2 buffer in order to remove all the bacteria from the well without disturbing the attached cells. A movie of 30 min was made in KK2 buffer where no bacteria were present. Subsequently, KK2 buffer was removed and $1 \mathrm{ml}$ of bacteria containing medium was added to the cells and a movie of 30 min was made. For publication purposes AVI format movies were prepared using Adobe Premiere (Version 6.0) software.

\section{Calculation of cell speed}

After recording the movies, in the above-mentioned three conditions, the data files of each cell type were used to analyse the locomotion of individual cells by using the motion analysis module of a software Metamorph (Version 6.1). The speed of individual cells was determined by dividing the total distance moved by that cell, between the first and last frame of the movie, with the total duration of the movie. Between 30-45 cells (shown as $n$ in the Results section) were analyzed in each condition for each cell type and the representative average speed of cells in a given condition, was calculated in three independent experiments. While observing these cells in the movie we noticed that some cells showed a clear linear motility whereas some other cells showed a concentric wriggling (round-and-round) type of motion without showing substantial linear displacement. The changes in cell speed under different nutrient conditions were subjected to the Student's $\mathrm{t}$-Test in order to assess their statistical significance.

\section{Calcium staining}

Dictyostelium discoideum (AX2) cells were grown axenically for 24-36 hours, were collected and washed twice with ice-cold KK2 buffer, centrifuged at $1900 \mathrm{rpm}$ for $5 \mathrm{~min}$ at $4^{\circ} \mathrm{C}$ and resuspended at $1 \times 10^{6} \mathrm{cells} / \mathrm{ml}$ in KK2 buffer were pre-incubated with $0.2 \%$ Pluronic F-127 for 5 min and thereafter, $2.5 \mu \mathrm{M}$ of FLUO-3 was added and maintained for 1 hour at $22^{\circ} \mathrm{C}$ under gentle stirring. The cells were again washed twice with ice-cold KK2 buffer and finally resuspended in KK2 buffer. These freshly starved cells were subjected to flow cytometric analysis and cell sorting was done using a MoFlo (Dako Cytomation/Beckman Coulter USA) high speed cell sorter. Low and $\mathrm{High} \mathrm{Ca}^{2+}$ cells were identified after setting the background autofluorescence levels and these 2 categories of cells were collected in $5 \mathrm{ml}$ tubes containing KK2 buffer. The sorted "High" and "Low" $\mathrm{Ca}^{2+}$ cells were centrifuged and plated in a 2 well chamber dish containing $1 \mathrm{ml} \mathrm{KK2} \mathrm{buffer}$ and their motility was analysed under these starvation conditions exactly as described above. These cells were also processed for immunostaining (described below). Each experiment was repeated thrice.

\section{Immunostaining and confocal microscopy}

The High and Low $\mathrm{Ca}^{2+}$ cells (AX2) obtained after sorting were plated separately in a 2- welled chamber dish in KK2 buffer. After time lapse imaging the cells were fixed with $3 \%$ formaldehyde at room temperature and permeabilized with $0.1 \%$ Triton $-\mathrm{X}-100$ for $8 \mathrm{~min}$ at room temperature, then washed twice with KK2. Cells were then treated with blocking solution $(0.3 \%$ BSA in KK2) for 30 min and then stained for 1 hour at room temperature with primary antibody (PTEN or PI3 kinase) diluted in blocking solution. Cells were rinsed twice in KK2 and incubated with secondary antibody conjugated to Сy 3 for $45 \mathrm{~min}$ in the dark, rinsed twice with KK2. The cells were then stained with Alexa Fluor 488 Phalloidin and incubated at room temperature in (dark) for 45 min washed with KK2 buffer and mounted in a mounting medium with anti-fade solution. These stained cells were viewed either with a Leica confocal microscope or with a Zeiss LSM 510 confocal microscope using appropriate objectives (63X) and the images were analyzed with different softwares supplied along with the microscopes. The quantification of co-localization of Actin-PI3Kinase or Actin-PTEN was calculated by pixel analysis using LAF software (Leica). The anterioposterior (AP) axis of the cells was calculated by using Zeiss Axiovision software. For PIP2 and actin staining, D. discoideum cells were plated on a cover slip and incubated at $22^{\circ} \mathrm{C}$ for $45 \mathrm{~min}$ for attachment and adherence. These cells were fixed and stained for Actin-PIP2 in the same procedure as mentioned above. The stained cells were observed under 
Axiovert 200M microscope using appropriate objective (100X).

\section{Motility analysis of Glucose ${ }^{+}$and Glucose- cells}

AX2 Cells were grown in Glucose deficient ( $\left.G^{*}\right)$ and Glucose sufficient $\left(\mathrm{G}^{+}\right) \mathrm{HL} 5$ media respectively (Garrod and Ashworth, 1972). $5 \times 10^{4} \mathrm{cells} / \mathrm{ml}$ were inoculated in $\mathrm{G}^{-}$and $\mathrm{G}^{+} \mathrm{HL} 5$ medium, and grown at $22^{\circ} \mathrm{C}$ with shaking at $1500 \mathrm{rpm}$ for 24 hours. Approximately $1 \times 10^{5}$ cells from each category were plated on a 2-welled, chambered cover glass and time-lapse movies of both cell types were made for a period of 30 min with a 10 second interval between the frames as described before. Motility-related parameters of these cells in their respective nutrient medium were calculated using Metamorph software.

\section{Development of reconstituted Glucose- and Glucose ${ }^{+}$cells}

Dictyostelium discoideum (AX2) cells were grown axenically for 24 hours, in $\mathrm{G}^{+}$and $\mathrm{G}^{-}$HL5 medium; cells were collected and washed twice with ice-cold KK2 buffer, centrifuged at $1900 \mathrm{rpm}$ for $5 \mathrm{~min}$ at $4^{\circ} \mathrm{C}$ and resuspended at $1 \times 10^{6} \mathrm{cells} / \mathrm{ml}$ in $\mathrm{KK} 2$ buffer and thereafter, $5 \mu$ of $\mathrm{DiD}$, a lipophilic cell membrane binding dye, prepared in cell labeling solution, was added only to the $\mathrm{G}^{+}$cells which were maintained for $20 \mathrm{~min}$ at $22^{\circ} \mathrm{C}$ under gentle stirring. The $\mathrm{G}^{+}$cells were again washed twice with ice-cold KK2 buffer and finally resuspended in KK2 buffer. The labeled $\mathrm{G}^{+}$and unlabeled $\mathrm{G}$ - cells were mixed in equal proportions, plated on $\mathrm{SM} / 5$ agar plate and incubated at $22^{\circ} \mathrm{C}$ for further development. The resultant fruiting bodies was viewed with a Leica confocal microscope using a 633nm laser and 63X PlanApo objective lens to check for the distribution of labeled and unlabeled $\mathrm{G}^{+}$and $\mathrm{G}^{-}$cells in the fruiting bodies. The reverse experiment was also done by mixing DiD labelled $\mathrm{G}^{-}$cells and unlabelled $\mathrm{G}^{+}$.

\section{Acknowledgements}

The work was supported by grant (No.MLP055, GAP0220) from the Council of Scientific and Industrial Research and the Department of Science and Technology, Government of India. We are thankful to Dr. O.G. Ramprasad for assistance in the preparation of the manuscript and Mr. G. Rajinikanth and Dr. Saby John for their contribution in the early stages of the work. We are also thankful to the lab members of GP and VN for their cooperation.

\section{References}

AZHAR M, SARAN S, NANJUNDIAH V (1995). Spatial gradients of calcium in the slug of Dictyostelium discoideum. Curr. Sci. 68: 337-342.

AZHAR M, MANOGARAN PS, KENNADY PK, PANDE G, NANJUNDIAH V (1996). $\mathrm{A} \mathrm{Ca}(2+)$-dependent early functional heterogeneity in amoebae of Dictyostelium discoideum, revealed by flow cytometry. Exp.Cell Res. 227: 344-351.

AZHAR M, KENNADY PK, PANDE G, ESPIRITU M, HOLLOMAN W, BRAZILL D, GOMER RH, NANJUNDIAH V (2001) Cell cycle phase, cellular $\mathrm{Ca}^{2+}$ and development in Dictyostelium discoideum. Int.J Dev.Biol. 45: 405-414.

BASKAR R, CHHABRA P, MASCARENHAS P, NANJUNDIAH V (2000) A cell typespecific effect of calcium on pattern formation and differentiation in dictyostelium discoideum. Int.J Dev.Biol. 44: 491-498.

BONNER JT (1952). The pattern of differentiation in amoeboid slime molds. Amer. Natur 86: 79-89.

BOSGRAAF L, VAN HAASTERT PJM (2009). The ordered extension of pseudopodia by amoeboid cells in the absence of external Cues. PLOS ONE. 4: 1-13.

BUKHAROVA T, WEIJER G, BOSGRAAF L, DORMANN D, VAN HAASTERT PJ, WEIJER CJ (2005). Paxillin is required for cell-substrate adhesion, cell sorting and slug migration during Dictyostelium development. J Cell Sci. 118: 4295-4310.

COMER FI, PARENT CA (2002). PI 3-kinases and PTEN: how opposites chemoattract. Cell. 109: 541-544.

DE FALCO KW, BENDER TA, SNEDDEN WA (2009). Breaking the code: $\mathrm{Ca}^{2+}$ sensors in plant signaling. Biochem. J. 425: 27-40.

DEVREOTES P, JANETOPOULOS C (2003). Eukaryotic chemotaxis: distinctions between directional sensing and polarization. J Biol Chem. 278: 20445-20448.
EVANS JH, FALKE JJ (2007). Ca2+ influx is an essential component of the positivefeedback loop that maintains leading-edge structure and activity in macrophages. Proc.NatI.Acad.Sci. USA. 104: 16176-16181.

FRALEY TS, PEREIRA CB, TRAN TC, SINGLETON C, GREENWOOD JA (2005). Phosphoinositide binding regulates alpha-actinin dynamics: mechanism for modulating cytoskeletal remodeling. J.Biol.Chem. 280: 15479-15482.

FUNAMOTO S, MEILI R, LEE S, PARRY L, FIRTEL RA (2002). Spatial and temporal regulation of 3-phosphoinositides by PI3-kinase and PTEN mediates chemotaxis. Cell. 109: 611-623.

GARROD DR, ASHWORTH JM (1972). Effect of growth conditions on development of the cellular slime mould, Dictyostelium discoideum. J. Embryol. Exp. Morph. 28: 463-479.

GIANNONE G, DUBIN-THALERBJ, DOBEREINERHG, KIEFFERN, BRESNICKAR, SHEETZ MP (2004). Periodic lamellipodial contractions correlate with rearward actin waves. Cell. 116: 431-443.

GILBERT SF (2000). Developmental Biology 6th edition. Sinauer Associates Inc. (Sunderland, MA).

IIJIMA M, DEVREOTES P (2002). Tumor suppressor PTEN mediates sensing of chemoattractant gradients. Cell. 109: 599-610.

IIJIMAM, HUANG YE, LUO HR, VAZQUEZ F, DEVREOTES PN (2004). Novel mechanism of PTEN regulation by its phosphatidylinositol 4,5-bisphosphate binding motif is critical for chemotaxis. J Biol Chem. 279: 16606-16613.

INOUYE K, TAKEUCHI I (1982). Correlations between prestalk-prespore tendencies and cAMP-related activities in Dictyostelium discoideum. Exp. Cell Res. 138: $311-318$

JAFFE LF (2010). Fast calcium waves. Cell Calcium. 48: 102-113.

JAISWAL JK, MUJUMDAR N, MACWILLIAMS HK, NANJUNDIAH V (2006). Trishanku, a novel regulator of cell-type stability and morphogenesis in Dictyostelium discoideum. Differentiation. 74: 596-607.

KING LB, FREEDMAN BD (2009). B-lymphocyte calcium influx. Immunological Reviews. 231: 265-277.

KOLSCH V, CHAREST PG, FIRTEL RA (2008). The regulation of cell motility and chemotaxis by phospholipid signaling. J Cell Sci. 121: 551-559.

LEACH CK, ASHWORTH J M, GARROD D R (1973). Cell sorting out during the differentiation of mixtures of metabolically distinct populations of Dictyostelium discoideum. J. Embryol. Exp. Morph. 29:647-661.

LI L, NØRRELYKKE SF, COX EC (2008). Persistent Cell Motion in the Absence of External Signals: A Search Strategy for Eukaryotic Cells. PLOS ONE 3: e2093.

LOSICK R, DESPLAN C (2008). Stochasticity and Cell Fate. Science. 320: 65-68.

MAEDA Y, MAEDA M (1973). The calcium content of the cellular slime mold, Dictyostelium discoideum, during development and differentiation. Exp. Cell Res. 82: $125-130$

MALCHOW D, MUTZEL R, SCHLATTERER C (1996). On the role of calcium during chemotactic signalling and differentiation of the cellular slime mould Dictyostelium discoideum. Int.J Dev.Biol. 40: 135-139.

MCDONALD SA, DURSTON AJ (1984). The cell-cycle and sorting in Dictyostelium discoideum. J. Cell Sci. 66: 195-204.

MEDALIAO, BECKM, ECKE M, WEBERI, NEUJAHR R, BAUMEISTERW, GERISCH $\mathrm{G}$ (2007). Organization of actin networks in intact filopodia. Curr.Biol. 17: 79- 84.

NANJUNDIAH V, SARAN S (1992). The determination of spatial pattern in Dictyostelium discoideum. J. Biosci. 17: 353-394.

RIDLEY AJ, SCHWARTZ MA, BURRIDGE K, FIRTEL RA, GINSBERG MH, BORISY G, PARSONS JT, HORWITZ AR (2003). Cell migration: integrating signals from front to back. Science. 302: 1704-1709.

SAMUEL EW (1961). Orientation and Rate of Locomotion of Individual Amebas in the Life Cycle of the Cellular Slime Mold Dictyostelium Mucoroides. Dev. Biol. 3: 317-335.

SANZ-MORENO V, GADEA G, AHN J, PATERSON H, MARRA P, PINNER S, SAHAI E, MARSHALL CJ (2008). Rac activation and inactivation control plasticity of tumor cell movement. Cell 135: 510-523

SARAN S, AZHAR M, MANOGARAN PS, PANDE G, NANJUNDIAH V (1994). The level of sequestered calcium in vegetative amoebae of Dictyostelium discoideum can predict postaggregative cell fate: Differentiation. 57: 163-169.

SASAKI AT, FIRTEL RA (2006). Regulation of chemotaxis by the orchestrated activa- 
tion of Ras, PI3K, and TOR. Eur.J Cell Biol. 85: 873-895.

SASAKI AT, JANETOPOULOS C, LEE S, CHAREST PG, TAKEDAK, SUNDHEIMER LW, MEILI R, DEVREOTES PN, FIRTEL RA (2007).G protein-independent Ras/ PI3K/F-actin circuit regulates basic cell motility: J Cell Biol. 178: 185-191.

SHU S, LIU X, KRIEBEL PW, HONG MS, DANIELS MP, PARENT CA, KORN ED (2010). Expression of Y53A-Actin in Dictyostelium Disrupts the Cytoskeleton and Inhibits Intracellular and Intercellular Chemotactic Signaling. J Biol Chem. 285: 27713-27725.

SMALL JV, STRADAL T, VIGNAL E, ROTTNER K (2002). The lamellipodium: where motility begins. Trends Cell Biol. 12: 112-120.

SOLL DR, WESSELS D, KUHL S, LUSCHE DF (2009). How a Cell Crawls and the Role of Cortical Myosin II. Eukaryotic Cell. 8: 1381-1396.

STRMECKI L, GREENE DM, PEARS CJ (2005). Developmental decisions in Dictyostelium discoideum. Dev. Biol. 284: 25-36.
SUIRE S, COADWELL J, FERGUSON GJ, DAVIDSON K, HAWKINS P, STEPHENS $L$ (2005). p84, a new Gbetagamma-activated regulatory subunit of the type IB phosphoinositide 3-kinase p110gamma. Curr.Biol. 15: 566-570.

TASAKA M, TAKEUCHI I (1981). Role of cell sorting in pattern formation in Dictyostelium discoideum. Differentiation. 18: 191-196.

VAN HAASTERT PJ, DEVREOTES PN (2004). Chemotaxis: signalling the way forward. Nat Rev Mol Cell Biol. 5: 626-634.

VAN HAASTERT PJM, BOSGRAAF L (2009). Food searching strategy of amoeboid cells by Starvation Induced Run Length Extension. PLOS ONE. 4: 1-7.

VICENTE-MANZANARES M, WEBB DJ, HORWITZ AR (2005). Cell migration a glance. J.Cell Sci. 118: 4917-4919.

WESSELS D, LUSCHE DF, KUHL S, HEID P, SOLL DR (2007). PTEN plays a role in the suppression of lateral pseudopod formation during Dictyostelium motility and Chemotaxis. J Cell Sci. 120: 2517-2531.

\section{Further Related Reading, published previously in the Int. J. Dev. Biol.}

Cell cycle phase, cellular Ca2+ and development in Dictyostelium discoideum.

M Azhar, P K Kennady, G Pande, M Espiritu, W Holloman, D Brazill, R H Gomer and V Nanjundiah

Int. J. Dev. Biol. (2001) 45: 405-414

Cell-cell signaling and adhesion in phagocytosis and early development of Dictyostelium.

E Bracco, B Pergolizzi, B Peracino, E Ponte, A Balbo, A Mai, A Ceccarelli and S Bozzaro

Int. J. Dev. Biol. (2000) 44: 733-742

A cell type-specific effect of calcium on pattern formation and differentiation in dictyostelium discoideum.

R Baskar, P Chhabra, P Mascarenhas and V Nanjundiah

Int. J. Dev. Biol. (2000) 44: 491-498

Dictyostelium discoideum: a model system for differentiation and patterning.

$\mathrm{R}$ Escalante and $\mathrm{J} \mathrm{J}$ Vicente

Int. J. Dev. Biol. (2000) 44: 819-835

On the role of calcium during chemotactic signalling and differentiation of the cellular slime mould Dictyostelium discoideum.

D Malchow, R Mutzel and C Schlatterer

Int. J. Dev. Biol. (1996) 40: 135-139

5 yr ISI Impact Factor $(2010)=2.961$

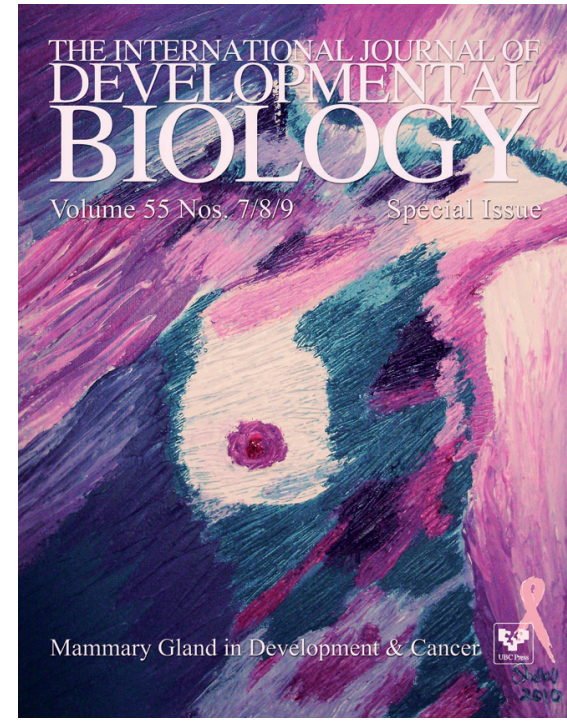

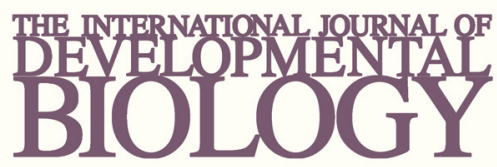

Volume 54 Nos. 6/7
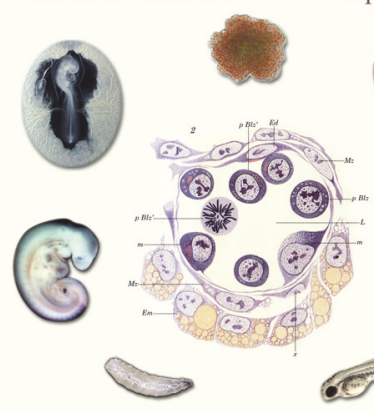

pecial Issue

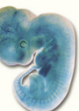

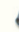

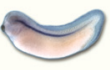

Developmental Hematopoiesis

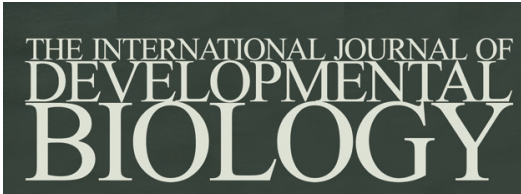

Volume 55 Nos. $4 / 5$

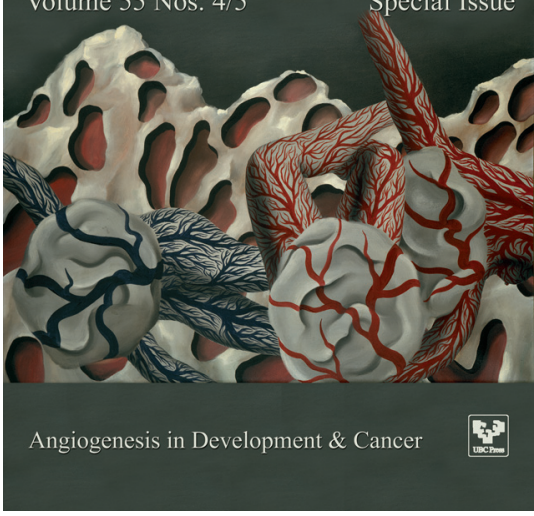

